\author{
Monika Grabowska, \\ Ph.D., Wroslaw University of Economics and Business, Poland \\ ORCID ID, 0000-0001-9627-0221 \\ email: monika.grabowska@ue.wroc.pl \\ Daria Kolesnyk, \\ Sumy State University, Ukraine \\ (iD) ORCID ID, 0000-0002-8983-5447 \\ email: daryakolesnik1211@gmail.com \\ Olha Matlai, \\ Sumy State University, Ukraine
}

\title{
RECOMMENDATIONS FOR INCREASING THE MOTIVATION OF MEDICAL STAFF ON THE EXAMPLE OF THE REGIONAL CLINICAL HOSPITAL
}

Abstract. This article discusses different aspects of increasing the motivation of health workers. The study's main purpose is theoretical knowledge about the practices of increasing the motivation of health workers. Systematization of literary systems and approaches to solving the problem Increasing the motivation of nurses using the Sumy Regional Clinical Hospital example indicates that the problem arose relatively long ago and scientists are looking for different ways to solve the problem. The urgency of solving this scientific problem lies in the fact that modern research methods are used and modern methods of solving the situation are proposed. Research of the topic Increasing the motivation of medical staff using the example of the General Clinical Hospital in the article is carried out in the following article: relevance of the problem, literature analysis, research results based on an anonymous questionnaire survey of the medical staff using the example of the Sumy Regional Clinical Hospital, recommendations for improvement, conclusions. The study was conducted using an anonymous survey of employees of the regional clinical hospital's neurological department in 2020. The research object is the relationships within the working collective of the neurological department, which are manifested in the improvement of the system of motivation of health workers. The article presents an empirical analysis of an anonymous survey, which showed the main gaps in the social work of the team of the neurological department. The study empirically confirms and theoretically proves that it is necessary to maintain the balance of psychological and economic agents and the main problem of employee dissatisfaction. The results of a study to improve medical staff's motivation using the example of a regional clinical hospital can be useful for heads of departments, different directions in medicine, and methodologists for working with teams.

Keywords: healthcare, medicine, medical reform, motivation in healthcare, motivation system, pandemic, personal motivation

Introduction. Human capital is a factor that significantly influences the activities and achievements of any organization. Health workers are vital to the health system's core functionality, but they are usually overlooked as a key element in the modernization of health systems. Nearly fifteen years ago, in 2006 WHO report, Working Together for Health, 57 countries reported a critical shortage of human resources. Skilled health workers migrate mainly from low- and middle-income countries to developed countries primarily for economic reasons and in response to poor working conditions and low job satisfaction. Ukrainian researchers also believe that the effective use of human resources is one of the main determinants of a medical institution's success since medical personnel, primarily doctors, are the producers of medical services.

Understanding assessments of motivation, identifying motivational factors for health workers and recognizing how a manager can successfully motivate staff are highly relevant issues of our time (Balcha

Cite as: Grabowska, M., Kolesnyk, D., \& Matlai, O. (2020). Recommendations for increasing the motivation of medical staff on the example of the regional clinical hospital. Health Economics and Management Review, 1, 60-68. http://doi.org/10.21272/hem.2020.1-05 
et al., 2015). Motivation is closely intertwined with the employee getting pleasure from work and in the future and keeps him in the workplace (Luoma, 2006)]. The medical workforce is motivated by a mix of social, professional and economic factors (Deussom et al., 2012). Motivation is closely related to incentives, and they must be combined to improve efficiency in favor of the enterprise.

Literature Review. According to Herzberg's theory of motivation, there are two types of incentive factors: 1) contentment (motivators), which are the main factors of job satisfaction, these include achievement, recognition, responsibility and career development; 2) dissatisfaction (hygienic factors), which are the main factors of dissatisfaction with work, these include working conditions, wages, relationships with colleagues, administrative policy and control (Herzberg et al., 1959]).

Herzberg used this model to explain that a person at work can be both happy and unhappy at the same time, since these two types of factors act as separate sequences. Thus, hygiene factors cannot increase or decrease pleasure; they only affect the level of discontent.

Motivation within the labor framework can be defined as the degree of a person's readiness to achieve an individual goal, corresponds to the organization's overall goal, mechanisms of behavior (both internal and external) and readiness to support these achievements (Franco et al., 2002).

Three models of solving problems of a social and labor nature are widely used globally, based on the experience of Japan, the USA and the countries of Western Europe.

One of the best in the world is the Japanese system, which encourages employees to be motivated and, as a result, to high staff productivity and fair wages. It has five components: life-long recruitment, personnel rotation, on-the-job training, reputation and remuneration, functioning as a complex mechanism that positively affects the training of highly qualified personnel, creating maximum conditions for realizing the potential of employees. Public authorities have the same influence on both the public and private niche of healthcare (Saijo et al., 2013).

In the United States, the system aims to improve the work of personnel through motivational factors, such as continuous diversity of work, full use of the creative, national and intellectual potential of their subordinates. In the US medical industry, wages are hourly, the working day lasts 8:00, that is, the motivational activity of this system works through employees, they are offered the maximum realization of their own potential, thanks to which a person can achieve professional success in a short time. On the other hand, with insufficient motivation, negligence in performing work, an employee may lose his status and encouragement at his workplace (Pegler, 2012).

In Austria, Germany, Sweden, the state plays an active role in regulating social and labor relations. Simultaneously, the principle of tripartism works in these countries, that is, the state, employer and employee solve problems with equal rights (Voltmer et al., 2012). Public health in France is trying to individualize the salaries of employees (Touraine, 2014).

Among the countries of Central and Eastern Europe, Ukraine has the lowest assessment of medical services quality (Stepurko et al., 2016). Life expectancy in Ukraine is the lowest in Europe. The medical reform of 2018 aims to optimize the financing of the provision of quality medical services, not at maintaining outdated infrastructure. Instead of the Unified Tariff, reorganized health care facilities use a contractual system of remuneration, the principle «Money follows the patient» is implemented. The newly established National Health Service of Ukraine implements this principle, which contributes to the legalization of the economic component of motivation for the medical community's best members.

Today in the health sector of Ukraine, the human resources management system has the following types of influence (Letunovska et al., 2020b):

1) economic, namely material incentives and sanctions based on the economic interests of employees, usually represented by wages and the system of additional payments;

2) administrative, based on a sense of duty, responsibility, understanding of the consequences, enshrined in the legal documents of the health care institution and its structural units; 
3) socio-psychological, which have a more personalized nature, contribute to intangible motivation.

Methodology and research methods. A situational analysis of Ukraine's human resources, conducted in 2018 with the United States Agency for International Development (USAID) support and the British Government's Good Governance Fund Program, showed that Ukrainian hospitals often disagree on financial and nonfinancial incentives within general (Bogdan et al., 2019). Jobs are provided with the minimum necessary to perform professional functions. This provision is insufficient to perform professional competencies and does not allow to comply with international standards to provide quality medical care. Medical staff does not have sufficient social protection.

Bilynska M. believes that this state of affairs has developed in the health care of Ukraine precisely because of the «unwillingness» of the authorities to reform the medical industry effectively, personnel «hunger» in medical management and inability to use modern principles of management in practical medicine (Bilynska \& Popchenk, 2006).

Authors L. V. Prokopets, I. M. Todoriko, D. D. Dyachuk, V. G. Guryanov, M. V. Shevchenko, Yu. B. Yashchenko, V. I. Borshch emphasize that Ukrainian physicians' material motivation is reasonably low, which negatively affects the quality of medical care (Prokopets and Todoriko, 2020; Diachuk et al., 2016; Borshch, 2016).

Studies conducted by I. V. Zamula and K. V. Szymanska show that the material motivation of labor depends on many factors, such as the level of wages and prospects for its growth, the level of wages from its results, reasonable wage differentiation in the enterprise, personal income and material support of the employee and his family (Zamula and Shymanska, 2011).

In 2013 , to identify the main motivational reasons, a survey of doctors of various specialties in Sumy was conducted (Borshch, 2016). This survey showed that most Sumy doctors are dissatisfied with living conditions, job security and wages. However, material incentives, respect for others and moral satisfaction from work are essential.

Even the introduction of medical reform's economic principles has not changed the fact that the main motivating factors in the medical industry are administrative and social, rationalization of working hours and corporate culture, the possibility of self-realization and professional growth, moral satisfaction and usefulness are the main drivers for most employees of Ukrainian hospitals (Smiianov et al., 2020).

2020 has united humanity in the fight against the SARS-CoV-2 virus, which provoked the Covid-19 pandemic. This pandemic has exposed many problems, gaps and shortcomings in the health sector of many countries. Ukraine is no exception (Kuzmenko et al., 2020; Letunovska et al, 2020a).

In our opinion, a set of organizational and economic measures to improve the quality of medical services in a pandemic should consist of the following components:

1) identification of motives for improving the quality of medical services;

2) comprehensive analysis of the situation in the medical field;

3) formation of a program to improve the quality of medical services;

4) implementation of the provisions of this program;

5) evaluation of the results of the effectiveness of medical services.

In the medical industry, it is challenging to use objective quantitative methods to analyze and evaluate professional activities, using expert methods that assess qualification requirements and professionally essential qualities. Systematic assessment of such factors and constructive dialogue between management and subordinates positively impact the development of in-hospital relationships.

Results. An anonymous survey was conducted among the neurology department of CNPE SR of Sumy Regional Clinical Hospital (6 doctors and 14 nurses). The sample contained 95\% of the medical staff of the neurological department of CNPE SR SRCH of the total number, which indicates its representativeness. The survey consisted of several blocks of questions that allowed to study the motives 
M., Grabowska, D., Kolesnyk, O., Matlai. Recommendations for Increasing the Motivation of Medical Staff on the Example of the Regional Clinical Hospital

of work, the reasons that keep at work and prevent the achievement of the desired result at work, to assess working conditions.

The gender distribution of employees was established: $80 \%$ of respondents were women. Among males, $75 \%$ were doctors. To study the motivation to work in the neurology department of CNPE SR $\mathrm{SRCH}$, respondents were offered answers that need to be rated on a 10-point scale, where 1- is the minimum score and ten is the maximum. The result of an anonymous survey showed that for employees of the neurology department, the leading incentives for work motivation, which were rated 10 points are moral satisfaction (70\%), success in work (65\%), professional duty (60\%), curiosity, the need to earn respect (55\%). The need for material support was the maximum value for only $25 \%$ of respondents.

The minimum scores (from 1 to 5) were answered in which the work motives were: work for recognition (55\%), control by the administration (45\%), the desire to increase the level of material comfort and the feeling of job satisfaction were at the same level (40\%).

The results of the assessment of work motivation factors both separately among doctors and nurses and in the sample as a whole are given in Table 1. No statistically significant discrepancy was found in the responses of physicians and nurses.

Table 1. The average score for assessing the factors of medical work motivation staff of the neurological department of CNPE SR SRCH

\begin{tabular}{cccc}
\hline $\begin{array}{c}\text { The main motive of the work } \\
\text { in the neurological department } \\
\text { CNPE SR SRCH }\end{array}$ & \multicolumn{3}{c}{ Average score } \\
\cline { 2 - 4 } & General & Doctors & Nurses \\
\hline The need for material support & 6,95 & 6,5 & 7,5 \\
\hline The desire to increase the level of material comfort & 6,3 & 8 & 6,4 \\
\hline Interest in work & 8,2 & 9,8 & 7,6 \\
\hline Professional duty & 8,8 & 9,6 & 8,9 \\
\hline Curiosity, the need to earn respect & 8,9 & 9,3 & 8,8 \\
\hline A sense of job satisfaction & 7,2 & 7,5 & 6,6 \\
\hline Control by the administration & 6,5 & 5,5 & 6,8 \\
\hline Work for recognition & 5,7 & 7,3 & 5,8 \\
\hline A sense of opportunity to succeed at work & 8,7 & 10 & 8,2 \\
\hline Moral satisfaction & 8,5 & 8,3 & 8,5 \\
\hline
\end{tabular}

Sources: developed by the author.

Although no significant discrepancies were found in the responses of doctors and nurses, their opinions differed somewhat. The maximum average scores of 10.0 and 9.8 among physicians, respectively, were the answers «Feeling the possibility of success at work» and «Interest in work». The same responses from paramedics were rated as 8.2 and 7.6, respectively (Figure 1). And the nurses have a maximum of 8.9 and 8.8 points - the answers «Professional duty» and «Curiosity, the need to earn respect», respectively. Physicians for these points had a score of 9.6 and 9.3 points.

The medical staff highly rated stability (7.75 points), guaranteed salary (6.75 points), psychological climate in the team (6.65 points) and personality of the leader (6.45 points). In contrast, factors such as social benefits (1.1 points), career growth (3.0 points), recognition of personal merit (5 points) and exciting work (5.35 points) received the lowest score. Again, in the absence of a statistically significant discrepancy in doctors and nurses' responses, their views were different. The average medical staff praised the psychological climate (7.5 points) and the presence of traditions in the team (7.0 points). 
M., Grabowska, D., Kolesnyk, O. Matlai. Recommendations for Increasing the Motivation of Medical Staff on the example of the Regional Clinical Hospital

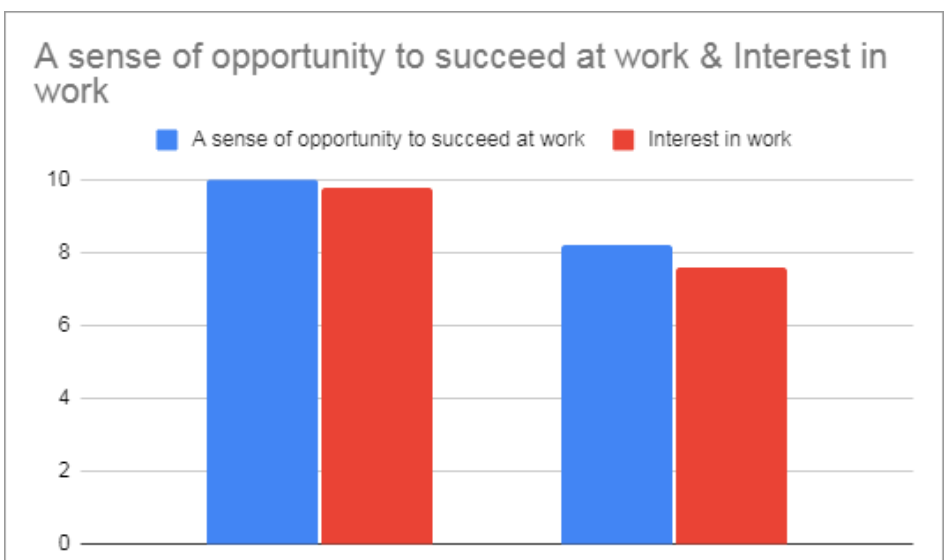

Figure 1. Distribution of the most popular answers regarding the motives of work in the Sources: developed by the authors. neurological department of CNPE SR SRCH

Table 2. Average score for assessing the factors that contribute to the retention of medical staff at work in the neurological department of CNPE SR SRCH

\begin{tabular}{lrrr}
\hline \multicolumn{1}{c}{ A factor that contributes to the work } & \multicolumn{3}{c}{ Average score } \\
\cline { 2 - 4 } & Genaral & Doctors & Nurses \\
\hline Guaranteed salary & 6,75 & 7,8 & 8,6 \\
\hline Interesting job & 5,35 & 4,6 & 5,3 \\
\hline Personality of the head & 6,45 & 5,3 & 7,2 \\
\hline Recognition of personal merits & 5 & 5,3 & 5,3 \\
\hline Stability & 7,75 & 7 & 6,8 \\
\hline Professional growth & 6,25 & 4,1 & 6,2 \\
\hline Social benefits & 1,1 & 1,1 & 1 \\
\hline Growth & 3 & 5 & 2,6 \\
\hline Psychological climate in the team & 6,65 & 3 & 7,5 \\
\hline The presence of traditions in the team & 6,25 & 3 & 7
\end{tabular}

Sources: developed by the authors.

For physicians, the evaluation of these criteria was much lower - 3.0 points.

Doctors rated the possible career growth higher -3.0 points, for medical sisters, this opportunity was not significant enough - 2.6 points.

The next block of questions of the questionnaire allowed to estimate the factors interfering with achievement of the necessary result in work. The achievement of the desired result was equally influenced by the large amount of work and stressful situations for $25 \%$ of respondents. For $20 \%$ of respondents, both the negative impact of work on health and the manager's attentive attitude to the suggestions of employees were equally important. Among the least important factors for medical staff were conflicts with the immediate supervisor (90\%), conflicts with patients (85\%), conflicts with relatives of patients $(80 \%)$, poor working conditions (75\%) and the inability to implement the latest technologies (60\%). 
M., Grabowska, D., Kolesnyk, O., Matlai. Recommendations for Increasing the Motivation of Medical Staff on the Example of the Regional Clinical Hospital

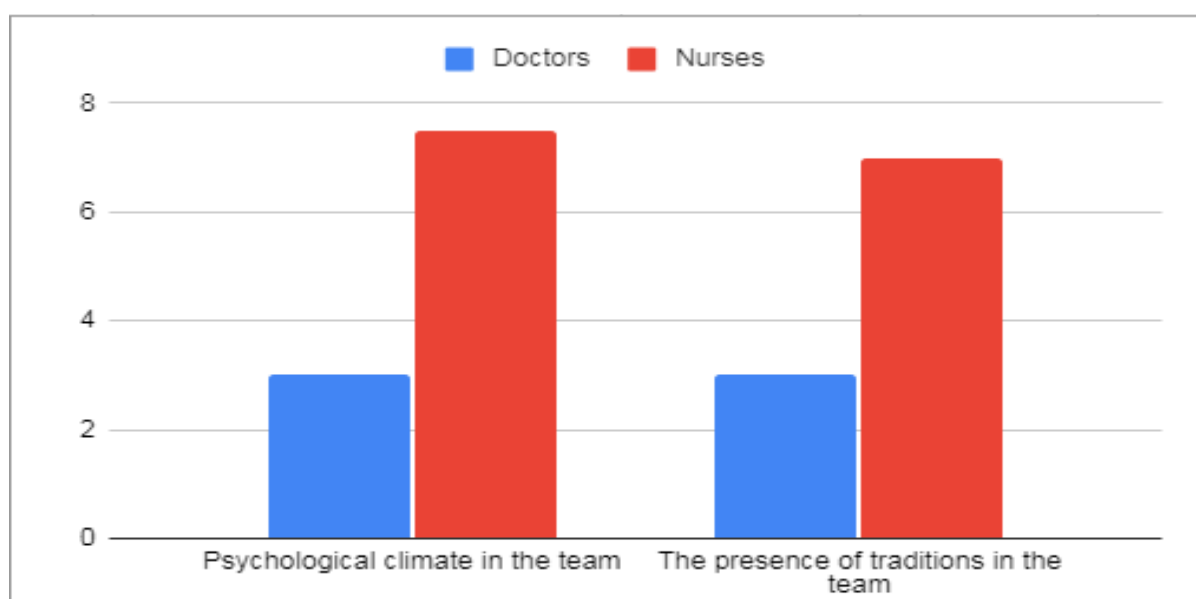

Figure 2. Distribution of the most popular answers about the motives for keeping medical staff at work in the neurological department of CNPE SR SRCH

Sources: developed by the authors.

Table 3. Average score for assessing the factors that hinder the achievement of the desired result in the work in the neurological department of CNPE SR SRCH

The factor that prevents the achievement of the desired result

Average score

\begin{tabular}{|c|c|c|c|}
\hline in the work & Genaral & Doctors & Nurses \\
\hline Large amount of work & 4,9 & 2,3 & 5 \\
\hline Conflicts with the immediate supervisor & 1,5 & 1 & 1,5 \\
\hline Conflicts with patients & 1,45 & 1,1 & 1,5 \\
\hline Conflicts with relatives of patients & 1,7 & 1,3 & 1,6 \\
\hline Poor working conditions & 2 & 18 & 22 \\
\hline Impossibility to express oneself & 3,1 & 4,8 & 3 \\
\hline Negative impact of work on health & 5,3 & 6,1 & 4,8 \\
\hline Stress at work & 5,8 & 6,8 & 6,2 \\
\hline Attentive attitude of the head to suggestions employees & 5,5 & 4,6 & 6,6 \\
\hline Inability to implement the latest technologies & 2,6 & 2,5 & 2,2 \\
\hline
\end{tabular}

Sources: developed by the authors.

The analysis found that the assessment of the surveyed factors that negatively affect to achieve the desired result in the work was generally low (Table 3). In the leading positions were the following answers: «Stress at work» - 5.8 points, «Attentive attitude of the head to the proposals of employees»- 5.5 points and «Negative impact of work on health» - 5.3 points. The lowest rated were: «Conflicts with patients» 1.45 points, «Conflicts with the immediate supervisor» - 1.5 points, «Conflicts with relatives of patients» 1.7 points, and «Bad working conditions» - 2 points.

The next block of questions revealed that for $85 \%$ of employees the psychological microclimate in the department was favorable (Fig. 3). At the same time, 15\% of respondents found it difficult to answer this question. For $50 \%$ of respondents, a change of leader would improve the psychological microclimate, $40 \%$ found it difficult to answer this question. And for only $10 \%$ of employees, the change of leadership did not improve the emotional atmosphere in the team. 


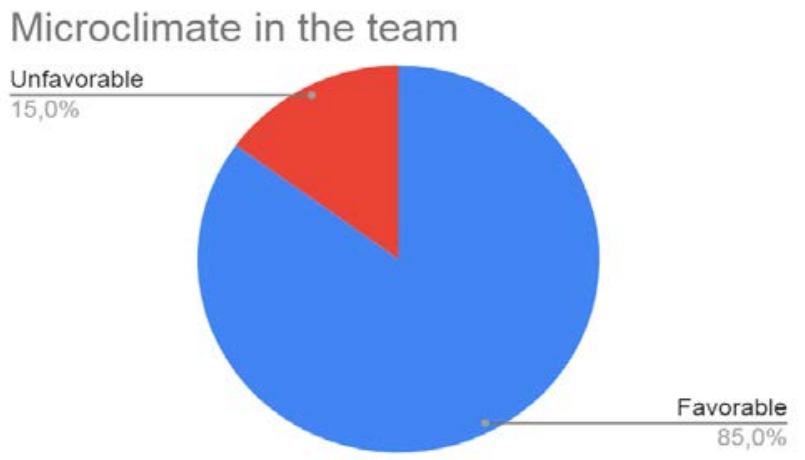

\section{Figure 3. Distribution of respondents' answers about the psychological climate in the staff of the} neurological department

Sources: developed by the authors.

The analysis of working conditions in the neurological department of CNPE SR SRCH revealed $75 \%$ of satisfied employees (Fig.4). At the same time, positive changes in this area are associated with a change in the chief physician, not the immediate supervisor.

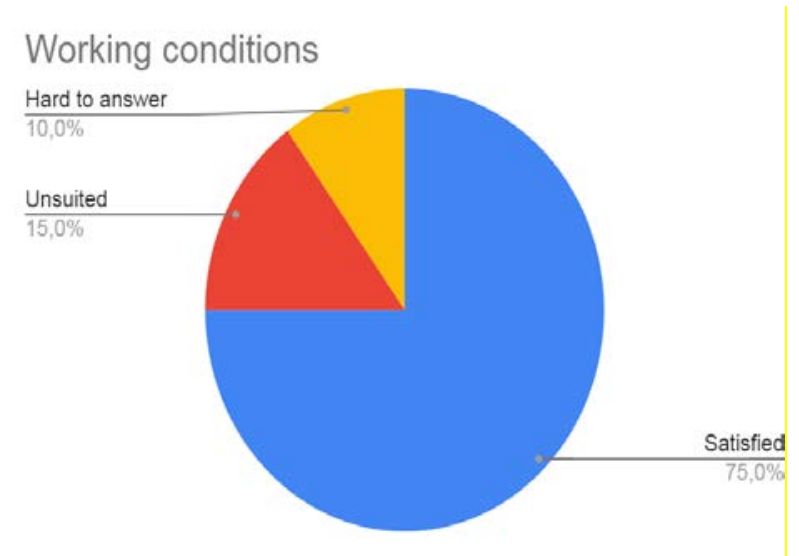

Figure 4. Distribution of respondents' answers on working conditions in the neurological Sources: developed by the authors. department

Ways to improve the motivation system of the staff of any medical institution by default require the modernization of the use of socio-psychological and economical methods. Deficiencies in staff motivation are corrected if employees' motivation to conduct through the prism of the institution's overall personnel strategy, both at the administration level and at the level of management salaries, are satisfied dissatisfied, challenging to answer the structural unit. The main agents of improving the motivation of neurology staff should be mastering the methodology of building a strong team, improving the system of material incentives following the achieved results, assessing efficiency, creating a personnel reserve, strengthening corporate culture, introducing new forms of training, possible long-term stable employment. Innovations in the system of motivation should be implemented indirectly by optimizing the work schedule 
M., Grabowska, D., Kolesnyk, O., Matlai. Recommendations for Increasing the Motivation of Medical Staff on the Example of the Regional Clinical Hospital

with a transparent system of time off, creating conditions for comprehensive development of employees, a creative approach to the use of intangible incentives and traditional incentives.

The training structure is based on the following principle: solve the problem the task is possible only under the conditions of team mutual assistance. Standard distribution team on managers and subordinates also does not remain - throughout team building programs, all team members work on the same basis. It helps to minimize stress in communication because the team leader can be each. In this case, if the team leader is the immediate supervisor, then trust and commitment to it will only grow. It is necessary to consider the individual and characterological features of employees and relationships in the team. It is desirable to carry out a preliminary diagnostics team and understand clearly what result you expect from the conducted training. Training in the corporate format are relevant during the pandemic outdoor recreation, but it is not a corporate party in the usual sense for us. On-first, it corresponds to preventive measures during a pandemic, and secondly, in new, one might even say, in an extreme environment, improving communication accelerates mental processes, which significantly accelerates and facilitates the teambuilding process. Interaction and a common goal make it possible that participants more clearly understand their team and perceive themselves as an integral part of the mechanism. Participation in such events allows employees to know each other better, expose your strengths and weaknesses, and develop a more appropriate program to achieve the appropriate goal. Implementation of acquired skills in everyday life will contribute, which is very important, to reduce the proportion of medical errors. One can organize teambuilding in two ways: on your own and with the involvement of third-party organizations that specialize in this activity.

Conclusion. The analysis of theoretical and methodical approaches to motivation is carried out by medical staff found that the most significant work efficiency possible to achieve a combination of both psychological and material motivating agents. Simultaneously, the maximum satisfaction of only one of these components will not lead to desired result.

Questionnaire of the staff of the neurological department of CNPE SR SRCH showed that the need for material support is not the main motivating factor. The leading incentives for employees are moral satisfaction (70\%), success at work (65\%) and professional duty (60\%). Simultaneously, the main reason for being employed in this department was guaranteed wages (70\%) and stability (40\%). As for the factors that hinder the achievement of the desired result in work, only stress and a large amount of work have a negative impact on employees. For $85 \%$ of employees, the team's psychological climate is favorable, and communication with the immediate supervisor is positive. Despite the total (95\%) dissatisfaction with wages, $80 \%$ of respondents want to continue working in this department.

Author Contributions: conceptualization, methodology, software, validation, formal analysis, investigation, resources, data curation, M. G., D. K.; writing-original draft preparation, O. M.; writing-review and editing, D. K.; visualization, O. M.; supervision, project administration, M. G.

Funding: This research received no external funding.

\section{References}

Balcha, Z., Ejigu, Y., Weldegebreal, F., \& Woldie, M. (2015). Motivation of health workers and associated factors in public hospitals of West Amhara, Northwest Ethiopia. Patient preference and adherence, 10, 159. [CrossRef]

Bilynska, M., \& Popchenko, T. (2006). Development of intellectual and personnel management in public health management. Public administration: theory and practice, 1. [Google Scholar]

Bogdan, D., Boyko, A., Vasylkova, A., Vezhnovets, T., ... \& Sereda, Yu. (2019). Human resources of the health care system in Ukraine. Situational analysis. Retrieved from [Link]

Borshch, Y. (2016). Research of motivational components of quality assurance of medical care in health care institutions based on the results of a survey of doctors of inpatient and outpatient departments. (Master's thesis, Sumy State University). [Google Scholar]

Deussom, R., Jaskiewicz, W., Dwyer, S., \& Tulenko, K. (2012). Holding health workers accountable: governance approaches to reducing absenteeism. Technical Brief, 3. [Google Scholar] 

the Regional Clinical Hospital

Diachuk, D., Hurianova, V., Shevchenko, M., \& Yashchenko, Yu. (2016). Satisfaction with working conditions and remuneration, the system of motivation of medical workers of a multidisciplinary health care institution. Ukrainian Journal of Medicine, Biology and Sports, (2), 63-69. [Google Scholar]

Franco, L. M., Bennett, S., \& Kanfer, R. (2002). Health sector reform and public sector health worker motivation: a conceptual framework. Social science \& medicine, 54(8), 1255-1266. [Google Scholar] [CrossRef]

Kuzmenko, O., Vasylieva, T., Vojtovič, S., Chygryn, O., \& Snieška, V. (2020). Why do regions differ in vulnerability to COVID19? Spatial nonlinear modeling of social and economic patterns. Economics and Sociology, 13(4), 318-339. doi:10.14254/2071789X.2020/13-4/20. [CrossRef]

Letunovska, N., Vasilyeva, T., \& Lyeonov, S. (2020). Modeling and forecasting the impact of the COVID-I9 pandernic on socioeconornic development. Szczecin : Cerltre of Sociological Research. [Link]

Letunovska, N.Ye., Vasilyeva T.A., \& Smiyanov, V.A. (2020b). Pandemic COVID-19 as a crisis-forming factor of healthy regions development. Visnyk of Sumy State University. Economy series, 3, 191-198. [Google Scholar]

Herzberg, F., Vauser, B., Snyderman, B. B. (1959). The Motivation to Work (2nd ed.). New York: John Wiley \& Sons.

Luoma, M. (2006). Increasing the motivation of health care workers. Capacity Project Technical Brief, 7. [Google Scholar]

Pegler, C. (2012). Herzberg, hygiene and the motivation to reuse: Towards a three-factor theory to explain motivation to share and use OER. Journal of Interactive Media in education. [Google Scholar]

Prokopets, L., \& Todoriko, I. (2020). Problems of personnel management in healthcare facilities. Market infrastructure, 42 Retrieved from [Link]

Saijo, Y., Chiba, S., Yoshioka, E., Kawanishi, Y., Nakagi, Y., Ito, T., ... \& Yoshida, T. (2013). Job stress and burnout among urban and rural hospital physicians in J apan. Australian Journal of Rural Health, 21(4), 225-231. [Google Scholar] [CrossRef]

Smiianov, V.A., Lyulyov, O.V., Pimonenko, T.V., Andrushchenko, T.A., Sova, S., \& Grechkovskaya, N.V. (2020). The impact of the pandemic lockdown on air pollution, health and economic growth: system dynamics analysis. Wiadomości Lekarskie, 73(11) 2332-2338. [Link]

Stepurko, T., Pavlova, M., \& Groot, W. (2016). Overall satisfaction of health care users with the quality of and access to health care services: a cross-sectional study in six Central and Eastern European countries. BMC health services research, 16(1), 1-13 [Google Scholar] [CrossRef]

Touraine, M. (2014). Health inequalities and France's national health strategy. Lancet (London, England), 383(9923), 1101 1102. [Google Scholar] [CrossRef]

Voltmer, E., Rosta, J., Siegrist, J., \& Aasland, O. G. (2012). Job stress and job satisfaction of physicians in private practice: comparison of German and Norwegian physicians. International archives of occupational and environmental health, $85(7), 819-828$ [Google Scholar] [CrossRef]

Zamula, I., \& Shymanska, K. (2011). Concept of employees motivation, its types and connection with accounting system. Problems of Theory and Methodology of Accounting, Control and Analysis, 20(2). [Google Scholar]

М. Грабовська, Ph.D., Вроцлавський університет економіки та бізнесу (Польща);

Д.є. Колесник, Сумський державний університет (Україна);

O.I. Матлай, Сумський державний університет (Україна)

Рекомендації щодо підвищення мотивації медичного персоналу на прикладі регіональної клінічної лікарні

У статті автори досліджують способи підвищення мотивації медичних працівників. Основна мета дослідження проаналізувати шляхи підвищення мотивації медичних працівників. Авторами зроблено висновок, що у медичній галузі складно використовувати кількісні методи для оцінки профессійної діяльності. Простіші та більш доцільні у використанні експертні методи, що дають можливість оцінити кваліфікаційні вимоги та профьесійно важливі якості персоналу. Систематична оцінка за цим методом разом із конструктивним діалогом з керівництвом спроможні позитивно вплинути на розвиток відносин усередині медичного закладу. Досліджено аспекти щодо підвищення мотивації медсестер на прикладі Сумської обласної клінічної лікарні. Авторами систематизовано літературні джерела та підходи до вирішення проблеми підвищення мотивації праці медичного персоналу. Пропозиції наведені на прикладі Сумської обласної клінічної лікарні. Дослідженняпроведене на основі анонімного опитування співробітників неврологічного відділення обласноі клінічної лікарні у 2020 р. Об'єктом дослідження є взаємовідносини в робочому колективі неврологічного відділення, які проявляються в удосконаленні системи мотивації медичних працівників. Представлені результати емпіричного аналізу анонімного опитування, яке показало основні прогалини в соиіальній роботі команди неврологічного відділення. Дослідження підтверджує, що необхідно підтримувати баланс психологічних та економічних фокторів, а також вирішувати основні проблеми незадоволеності працівників. Обгрунтовано, що максимальне задоволення лише однієї з иих складових не привозводить до бажаного результату. Серед факторів, що перешкоджають ефьективній роботі, стрес та значний обсяг роботи, які чинять істотний негативний вплив на працівників. Результати дослідження щодо вдосконалення мотивації медичного персоналу на прикладі обласної клінічної лікарні можуть бути корисними керівникам відділень різних напрямків у медицині, а також методистам для роботи з колективами

Ключові слова: охорона здоров'я, медицина, медична реформа, мотивація в охороні здоров'я, система мотивації, пандемія, особиста мотивація.

Manuscript received: 08.08.2020

(c) The author(s) 2020. This article is published with open access at Sumy State University. 